\title{
Optimizations of expression and purification of recombinant HIV- 1 CRF01_AE p24 protein in Escherichia coli for development of immunodiagnostic assay
}

\author{
Ade P.R. Simaremare, ${ }^{1}$ Budiman Bela, ${ }^{2,3}$ Andi Yasmon, ${ }^{3}$ Fera Ibrahim ${ }^{2,3}$ \\ ${ }^{1}$ Biomedical Programme, Faculty of Medicine, Universitas Indonesia, Jakarta, Indonesia \\ 2 Institute of Human Virology and Cancer Biology, Faculty of Medicine, Universitas Indonesia, Jakarta, Indonesia \\ ${ }^{3}$ Department of Microbiology, Faculty of Medicine, Universitas Indonesia, Jakarta, Indonesia
}

\begin{abstract}
ABSTRAK
Latar belakang: Metode konvensional untuk mengonfirmasi infeksi HIV adalah Western blot. Namun, western blot memiliki keterbatasan yaitu kontaminasi dengan antigen selular manusia dan masalah perbedaan genetik di antara subtipe HIV-1 yang menyebabkan hasil indeterminate dan ketidakakuratan diagnosis infeksi HIV-1 dengan strain spesifik. Pemeriksaan Western blot yang tersedia di Indonesia tidak spesifik terhadap infeksi subtipe CRF01_AE yang predominan di Indonesia. Pada penelitian ini dilakukan ekspresi, purifikasi dan Western blot terhadap protein p24 HIV-1 CRF01_AE rekombinan yang digunakan sebagai antigen.
\end{abstract}

Metode: Optimasi ekspresi protein rekombinan pada Escherichia coli galur BL21CP dilakukan terhadap waktu induksi, konsentrasi isopropyl-1-thio-d-galactopyranoside (IPTG) yang digunakan dalam induksi, dan suhu induksi. Purifikasi protein p24 rekombinan dilakukan dengan metode immobilized metal-affinity chromatography (IMAC) dengan sistem purifikasi Ni-NTA (Qiagen) pada kondisi native dengan optimasi pada konsentrasi imidazole dalam wash buffer.

Hasil: Konfirmasi protein rekombinan dengan Western blot menunjukkan bahwa ekspresi dan purifikasi protein p24 rekombinan telah dioptimasi dengan baik dan reaktif terhadap serum pasien HIV-1 positif di Indonesia.

Kesimpulan: Protein p24 rekombinan dari penelitian ini dapat dikembangkan untuk uji diagnostik Western blot berdasarkan subtipe CRF01_AE yang dominan di Indonesia.

\begin{abstract}
Background: Conventional method for confirmation of HIV infection is Western blot. However, it has limitations because of contamination by human cellular antigen and genetic diversity among the HIV-1 subtypes that show indeterminate result and inaccuracy for the diagnosis of different strains. Most of Western blot developed are based on HIV-1 B subtype. In Indonesia HIV-1 CRF01_AE subtype is dominantly circulated. Therefore, we optimized the expression, purification of the recombinant HIV-1 CRF01_AE p24 protein for development of immunodiagnostic assay.
\end{abstract}

Methods: Optimization of protein expression in Escherichia coli strain BL21CP was performed including induction time, isopropyl-1-thio-d-galactopyranoside (IPTG) and immidazole consentrations, and induction temperature. Purification of the recombinant p24 protein was used by using Ni-NTA (Qiagen) purification system in native condition.

Results: Expression and purification of HIV-1 CRF01_AE p24 protein have been performed. Confirmation of the recombinant protein by Western blot showed the expression and purification of recombinant p24 protein has been optimized well and reactive with sera of patients with HIV-1 CRF01_AE subtype positive.

Conclusion: The recombinant HIV-1 CRF01_AE p24 protein has been expressed and purified successfully, and it is potential to be used as antigen for immunodiagnostic assay.

Keywords: expression, HIV-1 CRF01_AE, p24 protein, purification, recombinant protein pISSN: 0853-1773• eISSN: 2252-8083• http://dx.doi.org/10.13181/mji.v24i1.1166• Med J Indones. 2015;24:14-8 - Received 02 Dec 2014 • Accepted 21 Feb 15

Correspondence author: Ade P.R. Simaremare, adepryta.mare@gmail.com

Copyright @ 2015 Authors. This is an open access article distributed under the terms of the Creative Commons Attribution-NonCommercialShareAlike 4.0 International License (http://creativecommons.org/licenses/by-nc-sa/4.0/), which permits unrestricted non-commercial use, distribution, and reproduction in any medium, provided the original author and source are properly cited. 
Human immunodeficiency virus type I (HIV-1) is a member of the lentivirus genus of the Retroviridae family. ${ }^{1}$ This virus consists of three clades i.e. $\mathrm{M}$ (main), $\mathrm{O}$ (outlier) and $\mathrm{N}$ (non-M, non- $\mathrm{N}$ ). The $\mathrm{M}$ group is divided into 9 subtypes $(\mathrm{A}, \mathrm{B}, \mathrm{C}, \mathrm{D}, \mathrm{F}$, $\mathrm{G}, \mathrm{H}, \mathrm{J}$, and $\mathrm{K}$ ) and 15 circulating recombinant forms (CRFs) ${ }^{2,3}$ In Asia, there are three dominant HIV-1 types (C, CRF01_AE and B) distributed in different regions. ${ }^{4}$ In Indonesia, HIV-1 CRF01_AE is a dominant subtype, followed by subtype B..$^{5-7}$

To date, HIV/ acquired immunodeficiency syndrome (AIDS) disease is a global pandemic problem. Globally, there were 34 million people with HIV in 2010, with approximately 1,8 million deaths. ${ }^{8}$ In Indonesia, there were 19,973 cases of AIDS diseases with 3,846 deaths in 2009. In 2013, AIDS cases increased up a total 43,667 cases with 8,340 deaths. The most HIV/AIDS cases were recorded in Papua, followed by East Java, and Jakarta. ${ }^{9}$

Accurate and reliable diagnostic assays are important to control the spread of this disease. ${ }^{10}$ Screening assays for diagnostic purpose must be capable to detect the anti-HIV-1 antibody in low titer and avidity particularly in the initial phase of HIV infection. The positive results of screening assays have to be confirmed by at least one confirmatory test. ${ }^{11}$ Many commercial HIV-1 p24 protein-based confirmatory assays for HIV infection have been developed. ${ }^{10-12}$ Most of the assays are based on p24 protein of HIV-1 B subtype. The assays can yield the indeterminate results due to the genetic differences among HIV-1 subtypes and/or CRFs. ${ }^{13}$ Since the dominant HIV-1 subtype in Indonesia is CRF01_AE, the application of the commercial assays is potential to lead the diagnostic inaccuracy in HIV1 infection. ${ }^{14,15}$ Therefore, in this study we optimized the expression and purification of the recombinant HIV-1 CRF01_AE p24 protein in Escherichia coli (E. coli) expression system. The optimizations can be used as preliminary data in producing recombinant HIV-1 CRF01_AE p24 protein for development of immunodiagnostic assays.

\section{METHODS}

\section{Expression and purification of recombinant HIV-1 1 CRF01_AE p24 protein}

The recombinant plasmid was isolated from $E$. coli Top10 culture based on the protocol of QIAprep Spin Miniprep Kit [Qiagen]. Gene encoding p24 protein was confirmed by DNA sequencing. The recombinant plasmid then transformed into $E$. coli strain BL21CP-RILP on heat shock method. The recombinant protein $(6 \mathrm{x}$ His tag- $\mathrm{N}$ protein fusion) was expressed by inducing the bacterial cells with $0.2 \mathrm{mM}, 0.5 \mathrm{mM}$, and $1 \mathrm{mM}$ isopropyl-1thio-d-galactopyranoside (IPTG) at $27^{\circ} \mathrm{C}$ and $37^{\circ} \mathrm{C}$ for 1-4 hours.

Bacterial pellets were solubilized in lysis buffer (300 mM NaCl, 0.1M EDTA, $50 \mathrm{mM} \mathrm{NaH}_{2} \mathrm{PO}_{4}, 10 \mathrm{mM}$ imidazole, pH 8.0 [Qiagen]) and freezed at $-80^{\circ} \mathrm{C}$ then thawed before sonicated to lyse the bacterial cells. The cell membran protein solubility and lipid eradication were performed by adding Triton-X 100 to the concentration of $1.5 \%$ (v/v). Purification of the recombinant protein was performed by following the manufacturer's instruction [Qiagen] with some optimization. Washing steps were performed 3 times. The optimization of recombinant p24 protein purification performed by different imidazole concentrations in wash buffer, namely $20 \mathrm{mM}, 30 \mathrm{mM}$, and $40 \mathrm{mM}$.

\section{Western blot}

The purified recombinant p24 protein was analyzed on $12 \%$ sodium dodecyl sulfate polyacrilamide gel electroforesis (SDS PAGE), The protein from the SDS PAGE gel was transfered to nitroselulose membrane by the Trans-Blot Semi Dry Electrophoresis Transfer Cell (Bio-Rad) in accordance with manufacturer's instruction.

The recombinant protein reactivity was analyzed by observing the bands on the strips indicating the reactivity of HIV-1 CRF01_AE recombinant protein to the sera of patients with HIV/AIDS CRF01_AE positive. The positive reactivity was compared with the positive and negative sera of the western blot commercial kit [MPDiagnostics].

\section{RESULTS}

\section{Expression of recombinant p24 HIV-1 CRF01} AE protein in E. coli BL21CP-RILP

The expression of recombinant protein was compared with to the wild type and non-induction controls. The migration range identified by the protein marker. According to analysis of the molecular weight, recombinant p24 protein is about $27 \mathrm{kDa}$ and migrate on the range of 25-30 $\mathrm{kDa}$ protein marker. 


\section{Optimization of induction time}

The expression of HIV-1 CRF01_AE p24 protein was inducted for four hours. The induction was performed by adding $1 \mathrm{mM}$ of IPTG concentration and incubated at $37^{\circ} \mathrm{C}$. The expression result showed in figure 1 . It showed that p24 protein migrated at range of 25-30 kDa protein marker. The band for the inducted protein was thicker than the non-inducted (lane 1) and the wild type proteins (lane 2-3). The thickest band can be observed on lane 8 which represented the p24 protein expression after four hours induction.

There can be observed that on migration range of 25-30 kDa were relatively thick band on lane 5-8

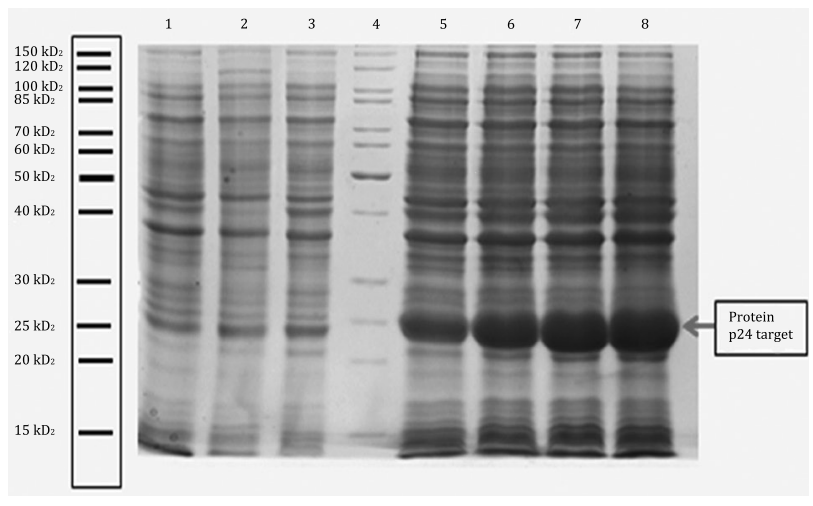

Figure 1. Electrophoresis gel of recombinant p24 protein expression by optimization on induction time. Lane 1: E. coli BL21CP pQE80L-p24 non-inducted; lane 2: E. coli BL21CP wild type; lane 3: E. coli BL21CP pQE81L wild type; lane 4: protein marker; lane 5-8: E. coli BL21CP pQE80Lp24 inducted at $37^{\circ} \mathrm{C}$ with IPTG $1 \mathrm{mM}$ for $1-4 \mathrm{~h}$

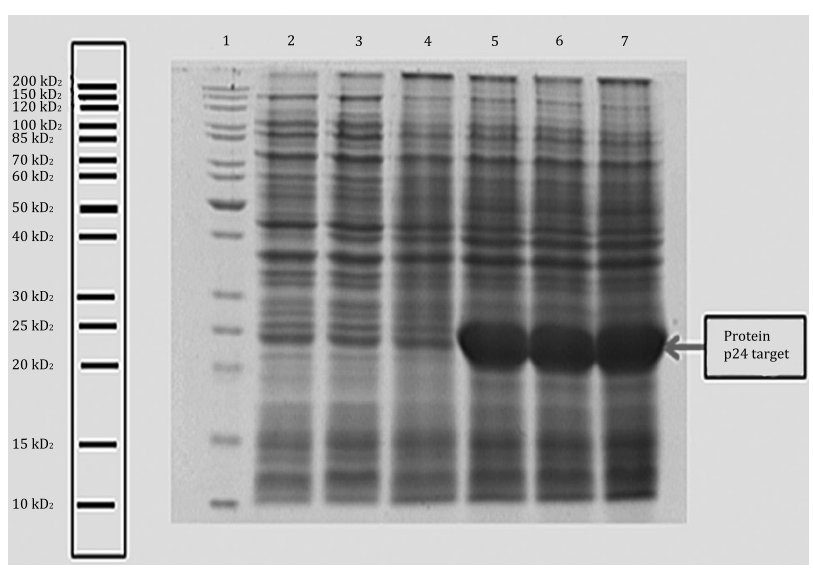

Figure 2. Electrophoresis gel of recombinant p24 protein expression by optimization in IPTG concentration. Lane 1: protein marker; lane 2: E. coli BL21CP wild type; lane 3: E. coli BL21CP pQE81L wild type; lane 4: E. coli BL21CP pQE80L-p24 non-inducted; lane 5-7: E. coli BL21CP pQE80L-p24 at $37^{\circ} \mathrm{C}$ for four hours inducted on IPTG concentration $0.2 \mathrm{mM}, 0.5 \mathrm{mM}, 1 \mathrm{mM}$ which represented the induction of recombinant p24 protein for one to four hours. The band for the inducted protein was thicker than the noninducted (lane 1) and the wild type control protein (lane 2-3). The thickest band can be observed on lane 8 which represented the p24 protein expression after four hours induction.

\section{Optimization of IPTG concentration}

Figure 2 showed the recombinant p24 protein expression on the optimization of IPTG concentration. It showed that the thickness of bands on migration range $25-30 \mathrm{kDa}$ were relatively equal on three of the IPTG concentration (lane 5-7).

\section{Optimization of induction temperature}

Figure 3 showed the recombinant p24 protein on the optimization of induction temperature. It showed that the band on migration range 25-30 $\mathrm{kDa}$ on lane 5 which represented the.

\section{Purification of recombinant p24 protein in native condition}

Figure 4 showed the bands on migration range 25-30 $\mathrm{kDa}$ for the elution 1-3 of purification for imidazole concentration $20 \mathrm{mM}, 30 \mathrm{mM}$, and 40 $\mathrm{mM}$. There can be observed that for the elution one and two of the three imidazole concentration were formed thick bands though with contaminant protein bands. However, on the elution three bands the contaminant protein bands begin to disappear. The most clean band can be observed

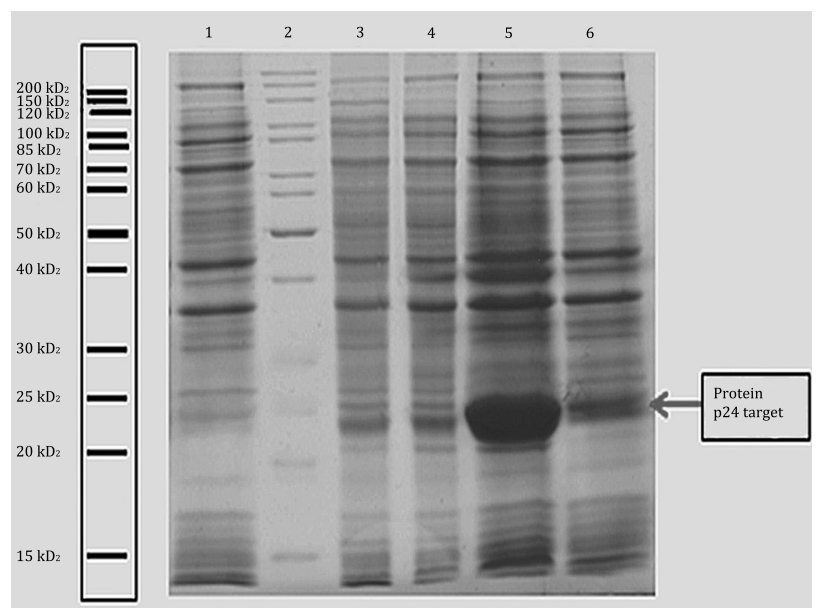

Figure 3. Electrophoresis gel of recombinant p24 protein by optimization of induction temperature. Lane 1: E. coli BL21CP pQE80L-p24 non-inducted; lane 2: protein marker; lane 3: E. coli BL21CP wild type; lane 4: E. coli BL21CP pQE81L wild type; lane 5-6: E. coli BL21CP pQE80L-p24 inducted with IPTG $1 \mathrm{mM}$ for four hours at $37^{\circ} \mathrm{C}$ and $27^{\circ} \mathrm{C}$ 
on lane 9 which represented the elution three with imidazole concentration $30 \mathrm{mM}$ in wash buffer.

\section{Recombinant protein confirmation by Western blot}

Western blot was performed by using the recombinant p24 protein as the antigen reacted with the antibody from the serum of people with HIV/AIDS and serum of positive and negative controls.

Figure 5 showed that there were band on the representative of the reactivity with the HIV-1

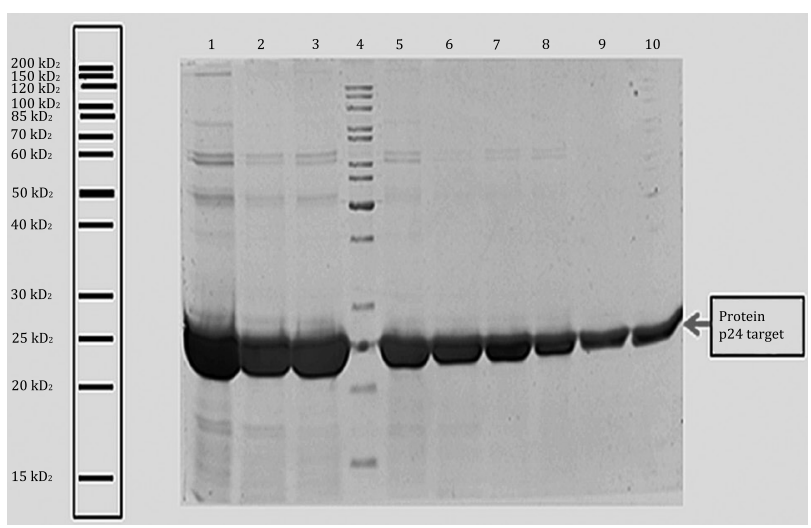

Figure 4. Electrophoresis gel of recombinant p24 protein purification in native condition by optimization of imidazole concentration in wash buffer. Lane 1-3: elution one with imidazole concentration $20 \mathrm{mM}, 30 \mathrm{mM}$, and $40 \mathrm{mM}$; lane 4-6: elution two with imidazole concentration $20 \mathrm{mM}, 30 \mathrm{mM}$, and $40 \mathrm{mM}$; lane 7: protein marker; lane 8-10: elution three with imidazole concentration $20 \mathrm{mM}, 30 \mathrm{mM}$, and $40 \mathrm{mM}$

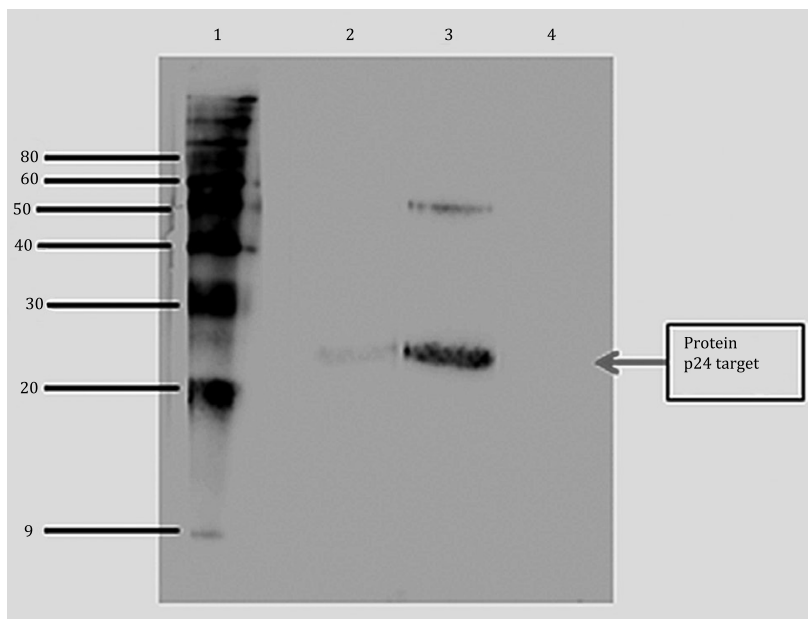

Figure 5. Western blot of p24 rekombinant protein. Lane 1: Biotin marker, lane 2: Reactivity of recombinant p24 protein with patient with HIV positive serum; lane 3-4: reactivity of recombinant $\mathrm{p} 24$ protein with positive and negative control serum of commercial kit positive serum patient on migration range 20-30 $\mathrm{kDa}$ (lane 2). On the reactivity with the positive control serum there were two bands on migration range 20-30 kDa and 50-60 kDa.

\section{DISCUSSION}

The SDS-PAGE analyze showed that recombinant p24 protein was overexpressed. The thick band formed for recombinant p24 protein affected by the expression system used. The codon translasional for recombinant p24 protein showed some codons that rarely recognize by the E. coli, the codons are for proL and $\arg U$. The expression system used in this research was E. coli BL21CPRILP containing addition tRNA copies for $\arg U$, ileY, leuW and proL that recognize the codons for arginin AGA/AGG, isoleusin AUA, leusin CUA, and prolin CCC. ${ }^{16}$ This addition tRNA was expected to overcome the codon limitation problem for protein translasional. Zang, et $\mathrm{al}^{17}$ and Singh, et $\mathrm{al}^{18}$ had overexpressed recombinant $\mathrm{p} 24$ protein in E. coli BL21(DE3). This result indicated that recombinant p24 protein was relatively highlevel expressed eventhough in conventional BL21 strain without tRNA addition.

The recombinant p24 protein purification performed in native condition and from the research performed by Zhang, et $\mathrm{al}^{16}{ }^{16}$ based on the densitometry analyze on SDS-PAGE for the pQE30-p24 recombinant expression in BL21 signify that his-tagged recombinant p24 protein was in solubel form. For purification of recombinant p24 protein the imidazole concentration used in wash buffer was optimized. Figure 4 showed the optimal imidazole concentration in wash buffer was $30 \mathrm{mM}$ in the third elution (lane 9). This imply the $30 \mathrm{mM}$ imidazole was capable to reduce nonspesific binding between Ni-NTA matrices and contaminant protein containing histidine residue. This nonspesific binding frequently occur in native condition purification than in denature condition, ${ }^{19,20}$ since the protein has denaturated in denature kondition purification (result not show). All the purification procedures in native condition performed at $4^{\circ} \mathrm{C}$ to avoid protein denaturation for optimal purification. The salt concentration for binding and washing was $300 \mathrm{mM} \mathrm{NaCl}$ to ensure the ion strength of the buffer. ${ }^{16}$ 
Figure 5 represented the Western blot for recombinant p24 protein and the recombinant p24 protein was reactive toward the HIV-1 positive patient serum and positive control commercial kit serum. This reactivity indicated that the patient serum infected by HIV-1 CRF01_AE has contained the spesific antibody for p24 HIV-1 CRF01_AE recombinant protein produced in this research. However, another protein band at migration range of about $55 \mathrm{kDa}$ was found in lane 3 for the reactivitity with the positive control serum. This addition band probably was the reactivity of antibody in positive control serum toward contaminant protein with molecular weight about $55 \mathrm{kDa}$. It can not be hindered that patient serum has the antibody for E. coli. However, in reactivity band toward the patient serum did not indicate contaminant protein of $E$. coli used as the expression system (lane 2). This result signify that recombinant $\mathrm{p} 24$ protein has been purified optimally with no E. coli contaminating protein. Another possibilities for the contaminated positive control reactivity were the improper storage of the commercial kit control serum and Western blot technique that cause contamination of unknown protein. Therefore, it is important to concern about the storage of commercially Western blot reagen including the control serum to ensure the reliability of the result. By this result can be concluded that the p24 HIV-1 CRF01_AE recombinant protein expressed in E. coli BL21CPRILP can be used as the antigen in Western blot assay for HIV-1 CRF01_AE diagnostic.

In conclusion, the recombinant p24 protein optimally expressed after four hours with induction of $0.2 \mathrm{mM}$ IPTG at $37^{\circ} \mathrm{C}$. The protein was purified optimally at the third elution and imidazole concentration of $30 \mathrm{mM}$ in wash buffer. The Western blot result indicated that the recombinant protein expressed in this study is potentially applied for immunodiagnostic assay of HIV-1 CRF01_AE infection in Indonesia.

\section{Acknowledgments}

This work was supported by Institute of Human Virology and Cancer Biology Universitas Indonesia and Directorate General of Disease Control and Environmental Health Republic of Indonesia.

\section{Conflict of interest}

The authors affirm no conflict of interest in this study.

\section{REFERENCES}

1. Abbas AK, Lichtman AH, Pillai S. Cellular and molecular immunology. 6th ed. Philadelphia: Saunders Elsevier; 2010.

2. Osmanov S, Pattou C, Walker N, Schwardländer B, Esparza J, WHO-UNAIDS Network for HIV Isolation and Characterization. Estimated global distribution and regional spread of HIV-1 genetic subtypes in the year 2000. J Acquir Immune Defic Syndr. 2002;29(2):184-90.

3. Knipe DM, Howley PM. Fields Virology. 5th ed. Philadelphia: Lippincott Williams \& Wilkins; 2007.

4. Lau KA, Wang B, Saksena NK. Emerging trends of HIV epidemiology in Asia. AIDS Rev. 2007;9(4):218-29.

5. Merati TP, Ryan CE, Spelmen T, Wirawan DN, Bakta IM, Otto B, et al. CRF01_AE dominates the HIV-1 epidemic in Indonesia. Sex Health. 2012;9(5):414-21.

6. Sahbandar IN, Takahashi K, Djoerban Z, Firmansyah I, Naganawa S, Motomura K, et al. Current HIV Type 1 Molecular epidemiology profile and identification of unique recombinant forms in Jakarta, Indonesia. AIDS Res Hum Retroviruses. 2009;25(7):637-46.

7. Roselinda R, Jekti RP. Genotype and transmission human immunodeficiency virus-1 in seven provinces in Indonesia. Health Science Indones. 2012;3(2):27-31.

8. World Health Organization. Global report: UNAIDS report on the global AIDS epidemic 2010. UNAIDS; 2011.

9. Direktorat Jenderal Pengendalian Penyakit dan Penyehatan Lingkungan Kemenkes RI. Statistik Kasus HIV/AIDS di Indonesia. Jakarta; 2013. Indonesian.

10. Luft S, Seme K, Poljak M. Laboratory diagnosis of human immunodeficiency virus infection. Acta Dermatoven APA. 2004;13(2):43-9.

11. Buttò S, Suligoi B, Fanales-Belasio E, Raimondo M. Laboratory diagnostics for HIV infection. Ann Ist Super Sanita. 2010;46(1):24-33.

12. Lakshmi V, Ponamgi SP. Evaluation of an indigenous western blot kit for human immunodeficiency virus. Indian J Med Microbiol. 2002;20(4):200-5.

13. Lal RB, Chakrabarti S, Yang C. Impact of genetic diversity of HIV-1 on diagnosis, antiretroviral therapy \& vaccine development. Indian J Med Res. 2005;121(4):287-314.

14. Icardi GC, Gabutti G. Multi-centre evaluation of RIBA ${ }^{\mathrm{TM}}$ HIV-1/HIV-2 SIA compared to HIV-1 Western blot. Journal of Preventive Medicine and Hygiene. 1998;39:57-64.

15. Phillips S, Granade TC, Pau CP, Candal D, Hu DJ, Parekh BS. Diagnosis of human immunodeficiency virus type 1 infection with different subtypes using rapid tests. Clin Diagn Lab Immunol. 2000;7(4):698-9.

16. Stratagene. BL21-Codon Plus Competent Cell. 2012. Available at: www.stratagene.com.

17. Zhang B, Liu D, Bao Z, Chen B, Li C, Jiang H, et al. High level soluble expression, one-step purification and characterization of HIV-1 p24 protein. Virol J. 2011;8:316.

18. Singh SC, Vasudevan M, Richa, Sinha RP. Novel method for the detection of HIV using rp24 recombinant protein from E. coli BL-21. Pharmacognosy. 2010;1(4):287-94.

19. The QIAexpressionist. A handbook for high-level expression and purification of 6xHis-tagged protein. 5th ed. Valencia: Qiagen; 2003. p.126.

20. Bornhorst JA, Falke JJ. Purification of proteins using polyhistidine affinity tags. Methods Enzymol. 2000;326:245-54. 